\title{
Two Tales about Illness, Ideologies, and Intimate Identities: Sexuality Politics and AIDS in South Africa, 1980-95
}

\author{
CARLA TSAMPIRAS* \\ History Department, Rhodes University, South Africa
}

\begin{abstract}
This article focuses on the micro-narratives of two individuals whose responses to AIDS were mediated by their sexual identity, AIDS activism and the political context of South Africa during a time of transition. Their experiences were also mediated by well-established metanarratives about AIDS and 'homosexuality' created in the USA and the UK which were transplanted and reinforced (with local variations) into South Africa by medico-scientific and political leaders.The nascent process of writing South African AIDS histories provides the opportunity to record responses to AIDS at institutional level, reveal the connections between narratives about AIDS and those responses, and draw on the personal stories of those who were at the nexus of impersonal official responses and the personal politics of AIDS. This article records the experiences of Dennis Sifris, a physician who helped establish one of the first AIDS clinics in South Africa and emptied the dance floors, and Pierre Brouard, a clinical psychologist who was involved in early counselling, support and education initiatives for HIV-positive people, and counselled people about dying, and then about living. Their stories show how, even within government-aligned health care spaces hostile to gay men, they were able to provide support and treatment to people; benefited from international connections with other gay communities; and engaged in socially subversive activities. These oral histories thus provide otherwise hidden insights into the experiences of some gay men at the start of an epidemic that was initially almost exclusively constructed on, and about, gay men's bodies.
\end{abstract}

Keywords: AIDS, Gay, Health Care Professionals, Sexuality, Sexual orientation, South Africa

\footnotetext{
* Email address for correspondence: c.tsampiras@gmail.com

I would like to acknowledge the Research Office at Rhodes University and the National Research Foundation (NRF) of South Africa for the financial assistance (through internal funding and via the Thuthuka programme, respectively) that allowed me to undertake this research. Thanks also to the editors and those reviewers who provided constructive comments for improving the article.
} 


\section{Introduction: Apartheid, AIDS, and the Politicisation of Homosexuality}

Reflecting in 2008 on AIDS in South Africa during the final phase of the anti-apartheid struggle and the transition to democracy, Edwin Cameron, AIDS activist and Justice of the Constitutional Court, observed that the transition period brought to the fore the intricate relationships that existed between illnesses, ideologies and (intimate) identities, resulting, in 'the unavoidable politicisation of homosexuality'. ${ }^{1}$ Indeed, as the oral testimonies in this article reveal, this politicisation of homosexuality often affected both public and private spheres, and, for two health care professionals on whose narratives this article focuses, their own sexual identity and personal and professional relationships with (gay) men dying of AIDS mediated the urgency of responding to AIDS. ${ }^{2}$

In July 1983 an article by five medical professionals reporting on the first officially documented AIDS cases in South Africa appeared in the South African Medical Journal. ${ }^{3}$ While the 'two cases' were not named in the journal article, their names had already appeared in certain South African newspapers. The initial responses by the 'general public' to the first documented cases were primarily characterised by fear and stigma and reflected prejudice, homophobia and 'moral panic' that were deeply rooted in the dominant conservative morality that pervaded South Africa in the 1980s. ${ }^{4}$ The men had primarily been identified as 'homosexual', 'white', flight stewards, not as two people who had died and would be mourned. ${ }^{5}$ Ralph Kretzen died on 26 August 1982 and Pieter Daniël (Charles) Steyn died on 1 January 1983, and we know very little about their personal histories.

We do however know that the association of the new syndrome with an undefined idea of 'homosexuality' replicated the initial link between 'homosexuality' and AIDS that had been made by the Centers for Disease Control in Atlanta, USA (CDC) in June 1981. ${ }^{6}$ In South Africa the initial association and official linking of AIDS with 'white'

${ }^{1}$ Interview with Edwin Cameron, Johannesburg, 7 February 2008. Cameron was one of the first high-profile South Africans to openly declare his HIV status and wrote about this experience in E. Cameron, Witness to AIDS (Cape Town: Tafelberg, 2005).

${ }^{2}$ Determining the most appropriate terminology to use when writing about sexual identity and sexuality remains important in the face of evolving (self) identities, sexuality politics and academic work in the field. See, e.g., P. Aggleton's discussion about and definition of sexuality in 'Researching same-sex sexuality and HIV prevention' in V. Reddy et al. (eds), From Social Silence to Social Science: Same-Sex Sexuality, HIV and AIDS and Gender in South Africa (Cape Town: HSRC Press, 2009). The use of terms such as LGBTI (lesbian, gay, bisexual, transgender and intersex) also requires elucidation as they have a history linked to changing sexuality politics landscapes. As with the constructions of any identities, there have been discussion about what it means to be gay and whether or not 'gay' sufficiently encompassed and reflected sexuality activists' identities and political agendas. In this article 'gay' is used to define homosexual cis-men who either self-identified as gay or belonged to organisations that self-identified as being gay organisations and represented gay men and/ or gay womyn (lesbians; for spelling of womyn, see note 16) and bisexual people. The term homosexuality refers to often unclear definitions prevalent in South Africa at the time that focused on sexual relations between people declared to be of the same 'sex', particularly men.

3 G. J. Ras, I. W. Simson, R. Anderson, O. W. Prozesky and T. Hamersma, 'Acquired Immunodeficiency Syndrome: A Report of Two South African Cases', South African Medical Journal, 64, 4, (23 July 1983), 140-2. With hindsight and knowledge of how the epidemic was to unfold in South Africa it is evident that people were already infected with HIV in at least the late 1970s. Nonetheless these two deaths were the ones that were officially recognised by the medical community and reported on in the South African media.

${ }^{4}$ L. Grundlingh, 'Early Attitudes and Responses to HIV/AIDS in South Africa as Reflected in Newspapers, 1983-1988', Journal for Contemporary History, 26, 2, (June 2001).

${ }^{5}$ Ibid.

${ }^{6}$ Centers [sic] for Disease Control (CDC), Morbidity and Mortality Weekly Report, 30, 21 (5 June 1981). An extract from the report can be found in M. Cochrane, When AIDS Began (New York: Routledge, 2004), 25. 
homosexual men by elites - both medical professionals guiding and directing early AIDS research and advising government departments and ministers; and people or organisations in positions of political power including government health departments and ministers, MPs and political parties - shaped and influenced responses, research, and narratives about AIDS in these and other spheres. ${ }^{7}$ The resultant moral outrage expressed in parliament, from pulpits and in conservative media provoked by this initial association did not allow for reflective discussion about sex and sexuality, but rather positioned 'homosexuality' and 'homosexuals' negatively in broader public spheres and, in so doing, politicised homosexuality. ${ }^{8}$

Moreover, authors of the hegemonic scientific narratives whether in medical journals, health care organisations or parliament often used the term 'homosexuality' only to refer to undefined sexual contact between 'white' men in a narrative which was preoccupied with an imagined middle-class, 'white', male, sexuality that was the primary referent against which normative and non-normative behaviours were judged. ${ }^{9}$ Drawing on narratives about AIDS primarily from the UK and the USA, influential medical practitioners and scientists, and politicians responsible for addressing AIDS in South Africa focused attention on this understanding of homosexuality and in doing so rendered invisible heterosexuals, lesbians, bisexuals, transgendered and intersexed people, and linked male homosexuality only to whiteness. ${ }^{10}$

In the 1980s, being gay in South Africa was a process mediated by apartheid legislation and questions of morality, 'race', sex, gender and class amplified by the socio-political and economic turmoil of the time. ${ }^{11}$ The oppressive, conservative, moral climate of

\footnotetext{
${ }^{7}$ For a detailed discussion on the creation of hegemonic AIDS narratives in medico-scientific and political communities and how these narratives influenced practical responses to AIDS see C. Tsampiras 'Politics, Polemics and Practice: A History of Narratives about, and Responses to, AIDS in South Africa, 1980-1995' (unpublished PhD thesis: Rhodes University, 2012). A full copy of the thesis is available on Academia.edu at www.academia.edu/2907679/Politics_Polemics_and_Practice_A_History_of_Narratives_about_and_Responses_ to_AIDS_in_South_Africa_1980_-_1995\#1 (accessed 11 February 2014). The thesis specifically examines the key medical journal of the time, the South African Medical Journal, government responses, and the responses and narratives evident in a progressive medical organisation and amongst members of the ANC's Department of Health in exile.

${ }^{8}$ See Tsampiras, op. cit. (note 7).

${ }^{9}$ C. Tsampiras 'Not So "Gay" After All: Constructing (Homo)sexuality in AIDS Research in the South African Medical Journal, 1980-1990', Southern African Historical Journal, 60, 3 (2008), 477-99. A note on 'race' and terminology: while acknowledging that 'race' is not real, the politics of constructing racial categories and the effects of this construction in terms of racism are very real. In South Africa, both during and after apartheid, racial identifiers and markers continue to be part of narratives in, and about, South Africa. As fraught, problematic, and constructed as racial markers are, they also mediated narratives about, and responses to, AIDS in South Africa and so their use is unavoidable in this article. When quoting from sources the racial designations of the time (as per the Population Registration Act of 1950) are used but spelled with lower-case letters to indicate their constructed nature. Some of the AIDS narratives discussed in this article drew from, or were premised upon, historical constructions of 'whiteness' and 'blackness' as ascribed to people considered to be phenotypically 'white' or 'black'. Few of the sources examined referred to people defined as 'coloured' or 'indian'.

${ }^{10}$ See Tsampiras, ibid., for more on the 'raced' and gendered representations of homosexuality.

${ }^{11}$ For more detail regarding the politics of health care provision and access during the period under discussion see Tsampiras, op. cit. (note 7), and for an analysis of activism relating to AIDS see M. Mbali, 'The New Struggle': A History of AIDS Activism in South Africa, 1982-2003' (unpublished PhD thesis: University of Oxford, 2009). For more on sexuality and sexuality politics at the time see S. De Waal and A. Manion (eds), Pride: Protest and Celebration (Johannesburg: Fanele, 2006); P. Ger, Homosexuality and Christian Faith in South Africa (Cape Town: David Philip, 1997); N. Hoad, K. Martin and G. Reid (eds), Sex and Politics in South Africa (Cape Town: Double Storey Books, 2005); M. Judge, A. Manion and S. De Waal (eds), To Have and To Hold: The Making of Same-Sex Marriage in South Africa (Johannesburg: Fanele, 2008); X. Li, 'Disjunctures within Conventional Knowledge of Black Male Homosexual Identity in Contemporary South Africa' (unpublished Master's thesis:
} 
South Africa did not allow sexuality organisations or LGBTI 'communities' to flourish, especially not in a context where (male) homosexuality - or more specifically, sodomy was illegal. ${ }^{12}$ While gay organisations and communities in the USA and UK had fought for, and built on, social changes in the 1960s and 1970s, in South Africa apartheid's effect on sexuality politics meant that corresponding socio-political gains had not been made. Despite this, some gay activists maintained international contacts with gay organisations and AIDS education organisations, resulting in a flow of information and exchange of ideas between South Africa and countries with more established and politically active gay communities.

Gay groups in South Africa were not necessarily concerned with addressing sexism, racism, homophobia or sexuality politics. Agendas ranged from providing safe social spaces to gather and talk, directing legal challenges to homophobic legislation and laws that discriminated against people because of their HIV status, to aligning the struggle for sexuality rights within broader anti-apartheid and international human rights campaigns. As Mark Gevisser and Edwin Cameron noted in one of the earliest and most influential works on the histories of sexualities in South Africa the two factors that exemplify 'homosexual experiences' in South Africa are 'the history of division and resistance' and 'the demographic divergence our country reflects'. ${ }^{13}$ They note that 'From the "developed world", we inherit notions of sexual freedom and gay subculture; from the "developing world" we gain the imperatives of struggle, resistance, and social transformation' ${ }^{14}$

Importantly, they add, "there is no single, essential "gay identity" in South Africa. What has passed for "the gay experience" has often been that of white, middle-class urban men' ${ }^{15}$ At the outset it was predominantly communities of urban, middle-class, 'white' men - with multiple gay identities - who came together to organise around AIDS and it is this 'community' that is most visible in the historical record. ${ }^{16}$

\section{Politics, Polemics, Practice, and the Personal: A Complex Nexus}

This article is drawn from a larger thesis project which explored how narratives about AIDS were constructed by elites in medico-scientific and political communities, and examined practical responses to AIDS by governments, the African National Congress

Rhodes University, 2009); B. Luirink, Moffies: Homo- en Lesboleven in het Zuiden van Afrika (Amsterdam: Jan Mets, 1998); R. Morgan and S. Wieringa (eds), Tommy Boys, Lesbian Men and Ancestral Wives: Female Same-Sex Practices in Africa (Johannesburg: Jacana Press, 2005); R. Morrell (ed.), Changing Men in Southern Africa (Scottsville, KwaZulu Natal, South Africa: University of Natal Press, 2001); O. Obono (ed.), A Tapestry of Human Sexuality in Africa (Johannesburg: Fanele, 2010); and G. Reid and L. Walker (eds), Men Behaving Differently: South African Men Since 1994 (Cape Town: Double Storey Books, 2005).

12 This said, as Conway has shown, there were also complex, and sometimes surreal, moments in South Africa's 'gay history' that highlighted the multifaceted interplay between ideologies and socio-political realities in the country. See D. Conway, 'Queering Apartheid: The National Party's 1987 Gay Rights Election Campaign in Hillbrow', Journal of Southern African Studies, 35, 4 (December 2009) 849-63.

${ }^{13}$ M. Gevisser and E. Cameron (eds), Defiant Desire: Gay and Lesbian Lives in South Africa (London:Routledge, 1995), 5.

14 Ibid.

15 Ibid., 3.

16 This is not to suggest that there were no (lesbian) womyn or gay 'black' activists, but rather that additional research is needed into their involvement. A note on the spelling of 'womyn': as a political marker of the socially constructed binary notions of human identity, and in recognition of the feminisms that have shaped my thinking, I use the spelling 'womyn' to refer to the group of people categorised as 'female'. Conventional spellings are used when quoting from sources. While conventional spellings are used for 'man' or 'men', these terms are also understood to be constructed and increasingly contested. 
(ANC) liberation movement in exile and progressive health movements. ${ }^{17}$ The thesis revealed the complex relationships between these communities, tracked the changing hegemonic AIDS narratives, and revealed the constructions of morality, 'race', gender and sexuality that infused them. It also showed how the relationships and narratives shaped and influenced practical responses to AIDS. Most of the sources used for this project were written sources which occasionally provided glimpses of the effects of narratives and practice on personal experiences, but none provided insights into the specific experiences of gay health care professionals. The relationships (nationally and internationally) between medico-scientific and political elites could be drawn out by combining written and oral sources, but the personal accounts of people at the nexus of the polemic and politics that combined to influence practical responses were hidden.

While accessible published work and archived sources provide insights into the experiences of progressive figures and sexuality activists, the stories of gay health care professionals living and working in a predominantly homophobic society and medical community at the start of an epidemic linked explicitly to 'white' gay men while important, were not readily available. ${ }^{18}$ Of the twenty oral interviews undertaken with medical professionals, political figures, activists and academics for the thesis, only two were with health care professionals who had openly declared their sexual orientation during the time period under discussion. Their stories offered unique perspectives and a way to record the effects of politics and polemics on people's lived experiences.

The article uses oral interviews to examine the experiences of two gay health care professionals addressing AIDS during the early years of the epidemic. It follows the example set by Gerald Oppenheimer and Ronald Bayer of recording the experiences of physicians and nurses in their book in Shattered Dreams: An Oral History of the South African AIDS Epidemic. Their book incorporates interviews with gay doctors, including Dennis Sifris and Steve Miller, and, in recording their oral histories, begins to address how some gay health care professionals experienced the epidemic. ${ }^{19}$ This article expands on the oral testimony of Sifris that appears in Shattered Dreams and contributes the oral testimony of Pierre Brouard. ${ }^{20}$

The face-to-face interviews with Sifris and Brouard were carried out in single sessions lasting from one and a half to two hours. They were recorded in 2008 using a digital voice recorder and verbal permission was sought and obtained from interviewees to record the interviews. While specific questions relevant to the professional experiences of each interviewee were devised, all interviews were predominantly open-ended and unstructured. During the interview notes were taken by the author, and the interviews were later transcribed. The purpose of the interviews and the nature of the research were also explained to each interviewee and they confirmed the accuracy and representation of their statements in the original chapter from which this article is drawn.

Sifris is a medical doctor who worked with one of the first South African medical researchers investigating AIDS, Ruben Sher, and helped to establish the AIDS Clinic at the large public and academic Johannesburg General Hospital (also widely

\footnotetext{
17 Tsampiras, op. cit. (note 7).

18 The Gay and Lesbian Archive (GALA) - now Gay and Lesbian Memory in Action - holds collections relating to the personal lives or work of activists involved in anti-apartheid politics, sexuality politics, and AIDS activism see the website for more information at www.gala.co.za (accessed 10 February 2014).

${ }^{19}$ G. M. Oppenheimer and R. Bayer, Shattered Dreams? An Oral History of the South African AIDS Epidemic (New York: Oxford University Press, 2007), 21.

${ }^{20}$ Brouard and Sifris agreed that their stories could be used for research purposes.
} 
known as 'Joburg Gen') and has been involved in AIDS education campaigns since the early 1980s. ${ }^{21}$ A clinical psychologist, Brouard was involved in some of the earliest counselling and support initiatives for people who were HIV-positive at a variety of venues, including the clinic at Joburg Gen, at ATIC (the first AIDS Training and Information Centre) that opened at the South African Institute for Medical Research (SAIMR) in 1987, and at the City of Johannesburg's Esselen Street sexually transmitted infection (STI) clinic in Hillbrow. ${ }^{22}$ Both Sifris and Brouard moved between and through the spheres of medical science, activism and sexual identity while attempting to address AIDS. While Sifris and Brouard are both professional, 'white', middle-class, urban, gay men, whose paths overlapped and who shared some similarities in their experiences of the early days of the AIDS epidemic, their professions, personalities and individual contexts resulted in different experiences. ${ }^{23}$ These early experiences laid the foundations for two men who, now both in their fifties, have spent almost three decades of their professional lives involved in AIDS health care and education.

Their personal reflections provide vignettes that contribute to understanding how narratives about, and responses to AIDS (and sexual orientation), affected individuals. Their stories provide insight into personal experiences of addressing AIDS in the early years of the epidemic when researchers and decision-makers were constructing a hegemonic AIDS narrative that was fundamentally conservative and homophobic. Their stories are micro-narratives that act as a counterpoint to the meta-narratives about AIDS featured elsewhere and act as a reminder of the emotional and psychological realities of an epidemic that continues to take lives, thus contrasting the 'unemotional' writing about AIDS in medical journals, the politically charged language in parliament or the official correspondence of political organisations. ${ }^{24}$

The article presents first Sifris and then Brouard's recollections of the early years of the epidemic and some of their reflections on sexuality, health care provision and AIDS after almost three decades as health care practitioners.

\section{Dennis Sifris: The Physician Who Emptied the Dance Floor}

Sifris and Sher began working together in the late 1970s after Sher had heard that Sifris had 'a large gay practice' and asked if he would collect serum samples for a Hepatitis B study. After the first official AIDS death in South Africa in 1982 they met to discuss further collaboration. Sher was based at the SAIMR and Sifris had his own practice in the city centre. While these collaborations would result in a long-term professional relationship, Sifris's experience as a physician involved in AIDS research was mediated by how colleagues and government officials responded to his sexual orientation as a gay man.

\footnotetext{
21 The Johannesburg General Hospital is now the Charlotte Maxeke Johannesburg Academic Hospital see www .johannesburghospital.org.za (accessed 11 February 2014).

22 The SAIMR is now the National Health Laboratory Service (NHLS) which was established in 2001: see NHLS website at www.nhls.ac.za (accessed 10 February 2014).

${ }^{23}$ In this article the personal narratives of the two informants are not subjected to critical discourse analysis as the point of the article is to represent and recount particular individual experiences that provide insights into the interplay between the socio-political contexts in which AIDS emerged in South Africa; the hegemonic AIDS narratives and responses that drew on specific ideas about sexuality and sexual orientation; and their personal experiences.

${ }^{24}$ Tsampiras, op. cit. (note 7).
} 
Soon after the first recognised AIDS deaths Sifris sought to address AIDS among 'the gay community' and contacted other gay doctors (an anaesthetist, a psychiatrist, and a neurosurgeon) to discuss what could be done. ${ }^{25}$ He recalled that, as a starting point in 1983, they 'put the word out in the gay community that there was this disease which nobody really knew about', while calling for volunteers to give blood samples to be sent to Sher at the SAIMR. ${ }^{26}$ Sher and Sifris compiled a questionnaire that followed research in the USA and UK and included questions about the number of sexual partners volunteers had, their medical history and current state of health, and their use of recreational drugs. ${ }^{27}$ To facilitate the work Sifris extended his practice hours to include Saturday mornings:

word got out and we actually got about 700-800 people coming to my office over a period of about four or five months and we pulled the bloods and we didn't quite know what we were looking for. We did a full blood count, we did an STD [sexually transmitted disease] profile and we stored bloods to see if there was anything we could find ....28

Sifris kept a list of names that linked volunteers - the majority of whom came from South Africa but also from countries such as Lesotho, Swaziland, Malawi, Zambia and Zaire - to their samples, but there was little that could be done medically to assist the increasing number of people who in the mid-1980s started to become sick and die. The lack of an effective medical response did not necessarily make the medical community in Johannesburg more interested in learning about other, non-medical, engagements and responses, however, as is evident from Sifris's account of a visit to Johannesburg by Glen Margo in 1985.

Margo, who was originally from South Africa, was involved in AIDS education in San Francisco. He contacted the Gay Association of South Africa (GASA) as he wanted to deliver talks about AIDS in Johannesburg. Sifris, a GASA member, agreed to arrange the lectures for Margo and organised one at the Department of Medicine at Joburg Gen. Sifris recalls:

There were all these cardiologists and respiratory physicians and this hippy San Francisco guy came along with handmade sandals and ringlets in his hair and told them about this funny [sic] disease that was affecting gay men that they should all be aware of . . . and he was almost laughed off as a joke. It was a wee bit embarrassing but that was the context of the medical community. ${ }^{29}$

\footnotetext{
${ }^{25}$ While definitions of 'gay community/communities' are contested, informants used the term indicating that their thinking was framed by a notion of communal identity. Sifris used the term 'gay community' but also noted that the gay community 'wasn't really in existence' in the mid-1980s.

${ }^{26}$ Interview with Dennis Sifris, Johannesburg, 26 February 2008.

27 While Sifris and Brouard both had professional and personal connections with sexuality organisations and individuals in other countries (particularly the UK and USA), in my interviews with them neither reflected nor commented specifically on engagements with organisations based in other African countries. The practical and/or political reasons for this would be an interesting line of further enquiry.

${ }^{28}$ Interview with Dennis Sifris. In addition to encouraging people to go to Sifris's practice, Quarraisha Abdool Karim (a leading global AIDS epidemiologist who was the first National Director of the HIV/AIDS and sexually transmitted disease (STD) Programme for the Department of Health from 1995 to 1996 and is currently the Associate Scientific Director of CAPRISA - the Centre for the AIDS Programme of Research in South Africa) recalls that Sher and Miller went on radio and asked concerned men to come for screening at the SAIMR. Her experience echoed Sifris's as she recalls 'long queues of men arriving from across South Africa, Swaziland and Lesotho. We were clueless took brief histories, took specimens, and ran every possible test'. Interview with Quarraisha Abdool Karim, UKZN, Durban, 19 November 2007.

${ }^{29}$ Interview with Sifris. 26 February 2008.
} 
It is unsurprising that medical elites in Johannesburg did not pay serious attention to a 'hippy' social worker talking about something that apparently only affected 'gays'. However, as Sifris was to discover, even being a medical doctor definedas 'non-hippy', 'white' and male, did not guarantee an attentive audience if one did not also 'pass' as heterosexual.

Despite the apparent lack of interest, Sifris and Sher persuaded hospital authorities to allow them to establish an AIDS Clinic at Joburg Gen in 1983. By 1985 Sifris was managing the daily running of the clinic and Sher moved between the clinic and the SAIMR. They decided to bring specialists from various fields, including respiratory illnesses and dermatology, into the clinic. Despite the dominant medical and popular association of AIDS with gay men, Sifris recalls that the first person they saw as an outpatient was an HIV-positive (then HTLV-III positive) womyn:

She came in and we ... sat there, eight of us doctors ... this poor woman came in, I still remember her sitting there. She didn't even know she was married to a bisexual man - she knew nothing about it . . and I think she was intimidated by all these doctors sitting there in their white coats. ${ }^{30}$

During the mid-1980s there was an increase in the number of patients attending the clinic and being admitted to the hospital with AIDS-related complex. Sifris observed some were 'the guys we had seen two or three years ago, who were friends of mine. A lot of them were SAA (South African Airways) people who were now getting sick and dying with this disease, and this was the time in the hospital where they were doing barrier nursing' ${ }^{31}$

In 1985 the Advisory Group on AIDS (AGA) was established by the Department of Health to advise the conservative and ostensibly Christian government led by the Nationalist Party on AIDS policy and Sher was invited to become a member. However, a medical background, an interest in AIDS, and experience researching and monitoring the epidemic did not guarantee membership of the Group, as Sifris discovered. He was told that he 'unfortunately' could not join because he belonged to a 'high-risk group' and '... if we have a gay man on the (AGA) we have to have a prostitute, we have to have a Haitian, and we have to have a black .... ${ }^{32}$

This decision made Sifris determined to 'just go ahead and do my own thing' so he called on medical professionals such as Steve Miller, Des Martin and Clive Evian (all of whom would become key AIDS researchers) to work with him at Joburg Gen; and, in conjunction with GASA, established an alternative AIDS group. Sifris and other '... concerned professionals and volunteers' formed the AIDS Action Group in 1985,

\footnotetext{
30 Ibid.

$31 \mathrm{Ibid}$. Being surrounded by medical professionals in biohazard suits was a common experience for AIDS patients for many years, as Shaun Mellors experience confirms. In 1986 Mellors was studying to become a teacher and worked part-time at a supermarket. He collapsed at work and was rushed to Joburg Gen where a doctor asked him if he had certain symptoms and if he was homosexual. Mellors confirmed that he was gay and the doctor left the room for a few minutes. When she returned she informed him that he had AIDS, despite not having taken any blood tests, and probably had about six months to live. Mellors spent two weeks in hospital undergoing tests without access to counsellors: 'I remember having endless groups of students coming in to have a look at me, to prod me, to feel me, to ask me questions but they all had the full space suit on before they would come in ... It was horrible and intense this two weeks of being prodded and . . eventually after they came and drew the blood and the test came back as positive they decided to discharge me. Then they referred me to Prof. Ruben Sher ... and he was the first person that actually said to me "It's ok - it isn't a death sentence"" (Interview with Shaun Mellors, International HIV/AIDS Alliance, Brighton, 8 September 2006). Mellors is still living with HIV and became a prominent international AIDS activist.

$32 \mathrm{Ibid}$. This story is also recounted, with variations in Oppenheimer and Bayer, op. cit. (note 19), 30.
} 
with the intention of providing 'psychological, social and concrete support services for people with AIDS and the AIDS-related complex'. ${ }^{33}$ The group sharedinformation about AIDS with interested parties and undertook education campaigns amongst sections of Johannesburg's gay community.

On trips to the USA and UK, Sifris gathered literature 'and came home with bundles of it'. ${ }^{34}$ The AIDS Action Group decided to distribute information leaflets and safe-sex cards in gay clubs in Johannesburg and approached club owners for support. In one club the Group set up 'a little (information) thing outside and people walked past and we said, "Hey, we are giving out safe sex cards", and everyone kept away from us!'. 35 On one occasion Sifris asked if the music in the club could be stopped at midnight so that he could make an announcement:

... so they stopped the music and I came out onto the dance floor with a microphone and I said, "listen this is not a police raid or anything, just relax, nothing is happening here, I just want to make everybody aware that there is a problem called HTLV-III which is affecting gays in America and all over the world" and everyone just moved away from me. I stood there in the middle of the dance floor trying to say, "Now listen people it is up to you to volunteer, to create awareness, to get the people aware, to give out pamphlets and please we have a desk in front, please come and sign". Two people came to sign. There was no interest, just apathy - like we were ruining the party. ${ }^{36}$

The pre-emptive declaration in Sifris's statement that his announcement was not part of a police raid speaks to the constant stress, suspicion and fear of arrest that was associated with being gay in South Africa. The majority of people in South Africa faced the constant threat of police and military violence by virtue of being declared 'black' in the apartheid state, and whiteness usually afforded privilege and protection to people declared 'white' by the state. While 'white' gay men maintained significant privilege in most socio-economic and political spheres, they did not maintain sufficient privilege to remain exempt from raids because of their sexual orientation. Similarly, 'black' gay men maintained some privileges by virtue of being male in a patriarchal system, but faced persecution for being both 'black' and gay.

The unwillingness of people to listen or respond to a potential health concern mirrors responses in most communities when faced with frightening news. ${ }^{37}$ It is not possible to determine how effective these interventions ultimately were, nor how much impact the distributed literature may have had on awareness raising. Nonetheless, it is significant that at a time when official responses to AIDS failed to cater for a group of people identified and constructed as 'high-risk', alternative, non-official efforts were made to raise awareness and provide support. ${ }^{38}$

The group decided to focus their energy on talks, engaging with the press and fundraising for AIDS-related work. Sifris and Sher were already giving talks for audiences

\footnotetext{
33 Interview with Sifris. 26 February 2008, and D. Sifris, 'Serological Test for AIDS', South African Medical Journal, 69, 9 (26 April 1986), 539-40. The AIDS Action Group never kept any formal records.

${ }^{34}$ Interview with Sifris, 26 February 2008.

35 Ibid.

36 Ibid. Incident recounted in Oppenheimer and Bayer, op. cit. (note 19), $26-7$.

${ }^{37}$ See K. J. Doka, AIDS, Fear, and Society (New York: Taylor and Francis, 1997), Part II.

38 This is not to suggest that the notion of high-risk groups was an appropriate one. For a discussion on the problematic and constructed nature of the hegemonic AIDS narrative produced by medico-scientific and political elites particularly around high-risk groups see Tsampiras, op. cit. (note 7), particularly ch. 1, 'Narratives of knowledge: Science, stereotypes, and AIDS in the South African Medical Journal, 1980-1995'.
} 
ranging from medical professionals to staff and students at schools, and to 'a group of Jewish single people over the age of 40'. Sifris gave talks to gay groups aroundthe country and spoke at the official opening of anti-apartheid activist Simon Nkoli's Township AIDS Project (TAP) in Soweto in 1990. ${ }^{39}$

Sifris both received calls from journalists seeking his expert medical opinion, and challenged journalists and editors about homophobic or inaccurate content in articles. He felt frustrated that many journalists were more concerned with writing sensationalist articles than with conveying educational information. These challenges extended to his engagements with the editor of Exit the longest running gay magazine in South Africa. Exit (originally known as Link/Skakel) started in the early 1980s as GASA's newsletter. It was renamed Exit in 1985 and published its 200th edition in 2006 when it cast a reflective eye on some aspects of its reporting on AIDS. Both Henk Botha and David Moolman edited the publication during the 1980s. Sifris criticised Moolman for running a sensationalist article about a person apparently getting AIDS from their dentist, rather than featuring comprehensive AIDS education information. ${ }^{40}$ Botha reflected on the early years of Exit:

During the 1980s a new 'gay disease' was discovered in America and eventually found its way here. Although we started publishing safe sex guides and lists of symptoms, very little was known about this mysterious killer affecting - at that stage - mostly gay men. This is where I, to my shame, made a crucial error. I am still haunted by the front-page headline that said something to the effect "Aids [sic] Scare Overrated". How wrong could I have been $?^{41}$

An exclusive 'black-tie' event and art auction launched the AIDS Action Group's fundraising initiative. Invitations targeted wealthy, 'white' gay men with disposable income. The event raised close to R10,000 for what was referred to as the 'AIDS Action Fund'. Another 'big gala fete' called 'Shaft 8' included information and education stalls and provided an opportunity to remember those who had died. Sifris

... set up a little AIDS stall ... and ... I bought those ... Jewish yahrzeit candles, and I laid out a table with one candle for each person who had died of AIDS. I think that was something like 32 people at the time -32 candles burning right through the whole night. It was my way of doing something to remember them ... 42

The Shaft 8 event raised a significant amount of money and brought 'all the gay communities together' - a gay Christian community, a support group called Outreach, a gay motorcycle group, and 'gay lesbians'. While AIDS may have connected these communities, it hardly united them. Sifris noted that there was 'all sorts of internal politics ... and stress' in the organisation. ${ }^{43}$ There was little engagement with any 'black' gays

39 GALA - Cameron Collection (AM 2629), Correspondence and Organisational Material, GLOW Newsletter Glowletter, June 1990. Simon Tseko Nkoli was an anti-apartheid activist who was arrested with other political leaders and tried for treason at the Delmas Treason Trial (1985-8). He was openly gay and is credited with positively influencing and shaping the attitude of key ANC leaders to sexuality (gay) rights. He spent several years in prison and on his release continued organising gay groups for black men and more progressive sexuality organisations such as the Gay and Lesbian Organisation of the Witwatersrand (GLOW). He publicly declared his HIV-positive status and organised support groups and education for HIV-positive men. He died of AIDS in 1998 and GALA holds a Simon Nkoli archive (Simon Tseko Nkoli - AM 2623).

${ }^{40}$ For more see the Exit website: H. Botha, 'Exit: Memories of the Early Years' at www.exit.co.za/frmArticle.as px?art=41; and G. Hayward, 'Exit @ 200: South Africa's Gay Newspaper' at https://groups.yahoo.com/neo/gro ups/newsclippings/conversations/messages/7735 (both accessed 10 February 2014).

${ }^{41}$ Botha, ibid.

${ }^{42}$ Interview with Sifris. 26 February 2008. In Judaism the death of a loved one can be commemorated annually by lighting a yahrzeit candle.

${ }^{43}$ Interview with Sifris. 26 February 2008. 
or lesbians and often a lack of gender sensitivity or awareness of racial prejudice. AIDS may have created spaces for collaboration and co-operation, but these spaces were not necessarily all-inclusive or self-reflexive; and addressing AIDS amongst a certain group of gay men who experienced discrimination did not amount to challenging the economic, social or racial position of that group of men, nor other forms of discrimination.

In order to increase fundraising opportunities and more effectively manage funds, the group needed an official fundraising number. ${ }^{44}$ It prepared a proposal outlining its plans to print pamphlets and undertake a countrywide outreach programme and had it endorsed by medical professionals, a professional in the finance sector, and people in the marketing and advertising sectors. The group presented the proposal to a representative from the Department of Health and asked for a grant of R20,000. However, because the organisations associated with the project were sexuality organisations, the fundraising number and the grant request were denied. ${ }^{45}$ The group made a presentation backing the grant request to 'Buks' Lombard, a member of the Department of Health in Pretoria. Lombard apparently listened carefully to the presentation and then said, 'You know, AIDS is not a problem in this country, TB is a problem in the country. Besides which homosexuality is illegal, and we don't have homosexuals, so we don't have AIDS'. ${ }^{4}$

\section{The Personal as Political: International Influences}

The Department of Health's rejection of the funding request meant the group was unable to initiate extensive AIDS education programmes based on those of the San Francisco AIDS Foundation, the Gay Men's Health Crisis, London Lighthouse, and the Terence Higgins Trust, whose pamphlets and programmes were the template for their own local campaigns. ${ }^{47}$ Thus, the content, politics and practice of AIDS education programmes developed by, and for, male gay communities in the USA and UK, shaped and influenced responses amongst some sectors of the male gay community in South Africa. For Sifris the frustration at not being able to implement 'ready-made' education programmes that could save lives was compounded by the denial of the very existence of homosexual men. This serves as a reminder of how groups of people were rendered 'invisible' in official apartheid discourse.

Had the grant had been successful, there is no guarantee that imported education campaigns would have been appropriate or effective in the South African context. However, in the absence of official responses or help for gay communities, they would at least have bolstered existing education efforts by gay organisations to prevent new

\footnotetext{
44 Under the Fundraising Act of South Africa, Act 107 of 1978 (amended in 1980, 1981, 1983 and 1991) organisations that wanted to fund raise had to be registered as a charity and apply for a fundraising number, subject to government approval of the organisations.

45 Miller recounts 'the government quite openly said we do not give fundraising numbers to criminals'. To circumvent this, gay organisations would collaborate with sympathetic organisations and use their fundraising numbers, see Oppenheimer and Bayer, op. cit. (note 19), 26.

${ }^{46}$ Interview with Sifris. 26 February 2008. Sifris stated, 'I only wish I'd had a tape recorder, because I quote verbatim and I remember.... what he said'.

${ }^{47}$ Interview with Sifris. 26 February 2008. Sections of this story are recounted in Shattered Dreams, 31, without reference to Lombard's comment about homosexuality being illegal.
} 
infections. ${ }^{48}$ Access to medical scientists and research organisations in the UK and USA shaped both Sifris's and Sher's professional engagement with AIDS, and contact with gay activists in these countries deeply influenced Sifris's personal and political outlook. $^{49}$

Sifris remembered going with Sher to a research laboratory in Bethesda, Maryland, and being 'drag[ged] into the halls of the Walter Reed Hospital in Washington or to some top-level research conference'. ${ }^{50}$ In 1985 Sifris went on ward rounds at the San Francisco General Hospital and at the AIDS unit in London, experiences that 'really opened (his) eyes' to the realities of the epidemic, the strategies being employed to address AIDS, and the remarkable solidarity and politicisation occurring around AIDS. ${ }^{51}$

Sifris had his most profound experiences at the points of intersection between personal, professional and political spheres. In the mid-1980s he attended an AIDS conference in Washington where members of the AIDS Coalition to Unleash Power (ACT-UP) protested over the lack of action in addressing AIDS. The conference changed Sifris's understanding of how people could organise politically to challenge medical and discursive responses to AIDS:

... Larry Kramer was there from ACT-UP and he was wearing a concentration camp uniform. At the time, and I thought this was very strange, he would shout and scream and carry on. They had a scientific session, and they had one or two sessions of people with AIDS and it was very funny because people stood up and said, 'I am so and so, and I have got HIV' - and everybody applauded, and everybody clapped for support ... it was really something special. I remember that to this day and I really learnt a hell of a lot [particularly] that there was a lot of mobilisation. ${ }^{52}$

During trips to London, New York and San Francisco, Sifris took part in AIDS memorials that made a lasting impression on him:

I was in Castro Street and they had it at Castro's station there, a candlelight memorial for Rock Hudson [it was] very moving. I remember seeing the memorial quilt in Vancouver, for the first time. They unfurled the quilt and there wasn't a dry eye in the house, everybody was crying .... 53

Contacts with gay organisations and (gay) doctors working on AIDS in the USA and UK were important in providing models of engagement, education, commemoration

${ }^{48}$ While further research is needed on the efficacy of campaigns amongst gay communities in South Africa, work by Nicoll et al.indicate that UK-based programmes by gay communities or organisations helped reduce infection rates. See A. Nicoll et al., 'Assessing the Impact of National Anti-HIV Sexual Health Campaigns: Trends in the Transmission of HIV and Other Sexually Transmitted Infections in England', Sexually Transmitted Infections, 77, 4 (August 2001) 242-7 available on the BMJ website at http://sti.bmj.com/content/77/4/242.full (accessed 10 February 2014).

49 Sher had contact with the Centers for Disease Control (CDC) and hospitals in the USA, and attended key international AIDS conferences, see: M. Mbali, (note 11), ch. 1; R. Sher and J. Metz, 'Third International AIDS Conference', South African Medical Journal, 72, 6 (19 September 1987) 444-6; and D. Sifris, 'Tribute: Remembering Ruben Sher', Southern African Journal of HIV Medicine, 8,3 (2007) 7 on the journals website at www.sajhivmed.org.za/index.php/sajhivmed/issue/view/5 (accessed 10 February 2014).

50 Sifris, ibid., 7.

${ }^{51}$ Interview with Sifris. 26 February 2008.

52 Ibid. Sifris dates the conference to June 1985, however ACT-UP was formed in 1987 when the International AIDS Conference was held in Washington, DC. It is possible that this was either another conference that Kramer participated in as a member of a pre-ACT-UP organisation (such as the Gay Men's Health Crisis) or that Sifris made a mistake with the dates. For more on ACT-UP and its history see the website at www.actupny.org and an interview with Larry Kramer, Interview no. 035, 15 November 2003, available at www.actuporalhistory.org/inte rviews/images/kramer.pdf (all websites accessed 10 February 2014).

${ }^{53}$ Interview with Sifris. 26 February 2008. At the Inaugural Professor Ruben Sher Memorial Lecture in 2008 at a Southern African HIV Clinicians Society meeting, Sifris again referred to the emotional impact that candlelight vigils, and AIDS memorials had on him (Sifris, personal copy of lecture). 
and grieving. For Sifris and others like Miller, who participated in conferences and marches overseas, these were spaces that demonstrated the potential for public protest, and subsequently influenced education and mobilisation efforts among sectors of the gay community in South Africa. ${ }^{54}$

On a trip to San Francisco a group called 'Physicians for Human Rights' invited Sifris to attend a braai (barbeque). Inspired by the experience of seeing doctors organise around political issues relating to the realisation of rights, Sifris decided to start a gay doctors' group in Johannesburg that numbered about twenty clinicians and met monthly at the HIV Clinic. Brought together by an interest in HIV, the primary aim was 'just to keep everybody up to date with HIV news', but 'eventually it just sort of fell to pieces because nobody was interested in coming anymore because there was not much more we could do'. ${ }^{55}$ It was only in the late 1990 s that Sifris, Des Martin and others decided to establish a new association, the Southern African HIV Clinicians Association. This was open to all clinicians involved in HIV work and included a number of gay doctors. Martin was appointed the first chair of the organisation and the first meetings were held at the National Institute of Virology. From small beginnings the organisation continued to grow and recently claimed to be 'the largest professional HIV interest group in the world, with over 12,500 members'. 56

The mid-1980s were particularly turbulent times in South Africa, both for anti-apartheid and sexuality activists. In 1986 GASA collapsed, but its demise, Gevisser notes, resulted in 'two new forms of gay political activity'. One 'found the notion of single-issue gay politics to be untenable in South Africa' and sought to align sexuality struggles with broader human rights and anti-apartheid struggles; the second 'insisted on fighting specifically for the reform of laws that discriminated against homosexuals'.57

In 1985 President P.W. Botha decriminalised 'interracial' (hetero)sex which had been made illegal by the Immorality Act, 1927 (amended in 1950). The Immorality Act also covered other 'sexual offences' such as prostitution and sodomy between men and Botha tasked an ad hoc committee with investigating these sexual offences, including homosexuality. This committee proposed: a strengthening of legal prohibitions against homosexuals; that greater effort should be made to determine how to appropriately 'rehabilitate or punish' homosexuals; and that a strategy should be formulated to express society's 'repugnance' for homosexuality. ${ }^{58}$

The collapse of GASA and the suggested law reforms had a direct impact on the AIDS Action Group and on organisations that had come together to raise money for AIDS programmes. Key gay activists established a National Law Reform Fund (NLRF) to fund challenges to the proposed legislation. The organisers of Shaft 8 were asked to consider reallocating the money they had raised to support the NLRF. Numerous meetings ensued

\footnotetext{
${ }^{54}$ In the Sher Memorial Lecture, Sifris recounted 'There were protest marches, and I remember marching at the Sixth International conference on AIDS in 1990 with the American Association of Physicians for Human Rights in Montreal. Steve Miller and I were so proud that we marched right next to June Osborn, who was the Dean of Medicine at the University of California, San Francisco, and Paul Volberding one of the first and foremost HIV specialists in San Francisco'.

55 Interview with Sifris. 26 February 2008.

56 Southern African HIV Clinicians Society website at http://sahivsoc.org/ (accessed 10 February 2014).

57 Gevisser, 'A different fight for freedom: A history of South African lesbian and gay organisation from the 1950s to the 1990s', in Gevisser and Cameron, op. cit. (note 13), 60.

58 Ibid.
} 
and Sifris recalls that 'it was decided among the committee that the Law Reform Fund was now more of an emergency than AIDS, so all the money was given over to the law reform committee. We thought we could always just raise more money for AIDS' ${ }^{59}$ Determining which threat - AIDS or the further criminalisation of homosexuality - was the more pressing could not have been an easy task, but the historical coincidence of the two issues coming into the spotlight at the same time detracted from plans toaddress AIDS. ${ }^{60}$ As it turned out, the investigations into homosexuality and law reform never got underway and the NLRF was transformed into a charitable trust. ${ }^{61}$

The late 1980s were also difficult times for Sifris and others working at the HIV Clinic at Joburg Gen, primarily because of the inherent homophobia and stigma associated with AIDS. Although Sifris and Sher had convinced hospital authorities to provide space for the HIV clinic it was not easily accessible to clients or visible, and both the name of the clinic, and who attended it, became contentious points. ${ }^{62}$ The clinic was initially called the 'Immune Disorders Clinic' but Sifris was adamant that after the identification and naming of the HI virus it was important for the clinic to be known as 'the HIV Clinic' to reduce the secrecy and fear associated with HIV. After several years of running the clinic on an honorary basis, Sifris was formally employed as its director in $1985 .{ }^{63}$ Despite vocal opposition, one of the first things Sifris did as director was to rename the clinic 'the HIV Clinic'. It retained that name until Sifris's resignation in 1990, when it was renamed 'the Immunity Clinic'. ${ }^{64}$

The hegemonic AIDS narrative of the time constructed gay men with AIDS as 'guilty offenders' who got AIDS because of their sexual orientation and 'deviant lifestyles' ${ }^{65}$ Conversely, haemophiliacs infected through contaminated blood products were constructed as 'innocent victims'. So strong was the stigma and homophobia that a separate clinic was established for haemophiliacs and others. Sifris recalled

... the haemophiliacs had their own clinic because they didn't want to come to the gay clinic - they didn't want to come to the HIV clinic, so they had their own clinic . . . . We never had anything to do with them - they didn't want anything to do with us because we were gays. ${ }^{66}$

Things came to a head for Sifris and Miller because of a devastating interplay between discrimination, drug pricing and public health care provision. In 1986 one of the first antiretroviral (ARV) drugs, Azido-Thymidine (AZT) also known as Zidovudine, came onto the market in the USA. As the first significant medical intervention for AIDS it was a breakthrough, but it was staggeringly expensive, costing approximately $\$ 10,000$ a year in

\footnotetext{
59 Interview with Sifris. 26 February 2008.

${ }^{60}$ Further research into the coincidental (or other) nature of this is required.

${ }^{61}$ In 1993 the Trust's funds were 'transferred to the Equality Foundation for lobbying for the inclusion of "sexual orientation" in the Equality Clause in South Africa's new Constitution', Hoad et al., op. cit. (note 11), 9.

62 The clinic was 'in a remote, even secluded, location' - Oppenheimer and Bayer, op. cit. (note 19), 35.

63 Sifris was appointed at one of the lowest paid skilled-wage levels and commented 'So I was the lowest of the low, in charge of one the largest HIV clinics on the continent'. Interview with Sifris. 26 February 2008.

64 Oppenheimer and Bayer, op. cit. (note 19), 35, and interview with Sifris. 26 February 2008. The clinic eventually returned to being called 'the HIV Clinic'.

65 This is evident, e.g., both in the pages of the South African Medical Journaland in parliamentary discussions recorded in Hansard see Tsampiras, op. cit. (note 9) and op. cit. (note 7), ch. 3, 'Between polemic and practice: Government responses to AIDS from the NP to ANC, 1982-1995'.

${ }^{66}$ Interview with Sifris. 26 February 2008. Miller is quoted as saying that 'any attempt to amalgamate services were absolutely rejected' by hospital authorities, Oppenheimer and Bayer, op. cit. (note 19), 35.
} 
the US at the time. ${ }^{67}$ The number of South Africans who could afford it when it was first distributed to the country in 1987 was minimal. While paying for the drug was completely impossible for most patients attending the HIV Clinic, it did at least provide hope because it prolonged the life of AIDS patients. The hospital eventually purchased AZT but only wanted to prescribe it to people with haemophilia. Sifris explains 'the hospital said we will give AZT to the haemophiliacs but we won't give it to the gay people because it is their own fault and haemophiliacs are innocent victims'. ${ }^{68}$

Livid at this blatant discrimination, Sifris contacted reporters and informed them of the hospital's policy, resulting in the story being featured in newspapers. ${ }^{69}$ Shortly afterwards the superintendent of the hospital informed Sifris that they had been called to a meeting with the Secretary of Health in Pretoria. At this meeting Sifris was reminded that as a member of staff of a public hospital he was not allowed to make statements to the media about hospital policy, and was duly admonished by the health secretary. As he recounted to me, Sifris 'went in and said "F. You", I now resign ... I don't want anything more to do with the hospital'. ${ }^{70}$ After Sifris's resignation Miller took over as head of the clinic, but was not in that position for long as he was told to leave by hospital authorities after supporting a patient's legal claim against the hospital. ${ }^{71}$

A final example of the ongoing frustrations experienced by Miller and Sifris related again to the AGA. Miller, like Sifris, had been excluded from joining the group because of his sexual orientation and his designation as a member of a 'high-risk group'. Nonetheless Sifris made a second attempt to join the group when it decided to expand its membership. Frustrated that the government had 'sewed together a bunch of old fogies who didn't do anything', Sifris thought that membership of the group might afford him the chance to facilitate change or action. In his application Sifris argued that as head of the largest HIV Clinic in the country he had considerable experience in addressing AIDS, which was augmented by the lectures he had given, the travelling he had done both regionally and internationally in connection with AIDS work, and the conferences he had attended. He also indicated that he would bring his 'own coffee cup in case you are worried that a gay man is going to infect you' ${ }^{72}$ Sifris's application was rejected, and the group appointed someone who 'had never seen an HIV patient in his life' ${ }^{73}$

While Sifris has never explicitly commented in interviews on the racial dynamics within GASA or any of the AIDS-related organisations that he was involved in, he did discuss the problems he and Sher faced at the clinic in the late 1980s 'getting black doctors

\footnotetext{
${ }^{67}$ Oppenheimer and Bayer, op. cit. (note 19), 40.

${ }^{68}$ Interview with Sifris. 26 February 2008.

${ }^{69}$ Attempts to locate the specific articles proved unsuccessful but a version of this account also appears in Oppenheimer and Bayers, op. cit. (note 19), 40.

${ }^{70}$ Interview with Sifris. 26 February 2008.

71 Oppenheimer and Bayers, op. cit. (note 19), 41. Miller had a patient who was going blind because of an opportunistic infection and was denied a drug that could reverse his condition by the hospital even though it was being offered to cancer patients. After supporting the patient's legal claim Miller 'became persona non grata' in the hospital. Ibid.

72 Interview with Sifris. 26 February 2008.

73 Ibid.
} 
involved' ${ }^{74}$ They organised a World AIDS Day event and wanted to invite 'black' doctors to attend but were unsuccessful: 'we searched and searched and searched and searched and couldn't find any black doctors to come out'.

They approached a prominent 'black' doctor in Soweto with known links to the ANC but were turned down. Sifris speculated that 'black' doctors 'weren't interested because it was not a 'black' problem, it was a gay disease. It was a gay disease and nobody worried about the gays'. ${ }^{75}$ Because AIDS was not being identified among 'black' patients, and places like the HIV Clinic were either not legally integrated or welcoming of 'black' patients, it was not seen as important amongst 'black' health care professionals. The hegemonic narrative of AIDS as a 'white', gay, male disease would certainly have shaped this perception. There are complex reasons why 'black' doctors may not have wanted to participate in the events, not least of which were the other health concerns exacerbated by apartheid which at the time were regarded as being more pressing.

In the early days of the epidemic, Sifris recounts, it was difficult coping with the deaths, government and community inaction, and general homophobia. He realised that he was displaying many of the symptoms of 'burnout'. Added to the stresses and strains of battling government and hospital officials, he experienced a personal loss that caused him to withdraw from professional and public spheres. Sifris met an HIV-positive man at an AIDS conference in Stockholm and the two fell in love and lived together for five years. As his partner's health began deteriorating, the couple travelled to Sweden for treatment twice a year. After his partner suffered a mini-stroke that left him paralysed, the couple decided that he needed to return to Sweden to see his doctors and be with his family. As he recalled some twenty years later, while they were in transit at Brussels airport, Sifris's partner suffered a major stroke and a massive brain haemorrhage: '.. as we were getting onto the plane he collapsed and died. So, I sort of withdrew at that time a little bit, but (since then) I've slowly gotten back' ${ }^{76}$

In 2013, Sifris has semi-retired but continues to deliver lectures on AIDS, acts as a medical consultant to a disease management company, and contributes health information to Exit and other media fora. ${ }^{77}$ Having seen so many people die of AIDS over the course of three decades, Sifris expressed disappointment in the interview that successive post1994 democratically-elected South African governments have put up so many barriers to procuring and distributing life-saving drugs.

His recollections reveal the inherent and blatant homophobia that gay men experienced, regardless of their 'race' or class. Frustration at official inaction around AIDS and the reality of friends, colleagues and lovers dying, provided the impetus for Sifris and others to mobilise in the early 1980s, soon after the seriousness of the epidemic was becoming apparent to them. The importance of international connections and experiences is evident in Sifris's personal politicisation around AIDS. As a doctor involved in the first HIV clinic in South Africa, his professional status and resources allowed him to travel to international conferences and connect with other doctors and with gay organisations addressing AIDS,

\footnotetext{
${ }^{74}$ Ibid.

75 Ibid.

76 Ibid.

77 Sifris and his partner James Myhre contribute to the health section of Exiton topics such as HIV and sexual health.
} 
and to bring important information and ideas back to sectors of the gay community in South Africa.

While Sifris and Brouard were both involved in addressing AIDS as health care practitioners, they occupied different positions in the health care facilities they worked in, and their experiences correspond and contrast each other, as will be shown below.

\section{Pierre Brouard: Counselling for Death, Counselling for life}

Pierre Brouard is a clinical psychologist and currently the Deputy Director of the Centre for the Study of AIDS at the University of Pretoria. Brouard's recollections on the early days of the AIDS epidemic are noticeable for their reflexive and contemplative nature. His discussions about the epidemic, and his involvement in various counselling and support positions, are imbued with a critical awareness of the broader socio-political landscape of South Africa during the 1980s and early 1990s.

Brouard came out in the late 1970s and believes that coming out before AIDS was 'on the scene' shaped his sexual identity in a different way to people who were coming out during the epidemic and helped form his perspective on the fears and considerations that framed peoples' sexual lives.

Reflecting on the late 1970s, Brouard view was that one of the key issues that concerned many ('white') gay men at the time was that homosexuality was illegal. Under the Immorality Act and subsequent amendments, there was the continued threat of being arrested, harassed, hounded, shamed or imprisoned. Legal concerns aside, from a personal physical health perspective the most immediate health concerns were STIs such as herpes, syphilis or gonorrhoea, all of which were treatable. While fear of the law remained, in the early 1980s physical health priorities were to be radically altered as the 'first murmurings ... that something was amiss started to surface' with news often coming from 'middle class, white, gay men' who travelled internationally, and from people working in the airline industry. ${ }^{78}$ The murmurings turned into reports of a 'new disease' that was framed entirely as a gay disease, complete with the acronym GRID (Gay-Related Immune Deficiency).

Central to both Brouard's and Sifris's narratives, is the importance of international travel and networks for transmitting information about AIDS. Brouard remembers that people who travelled internationally 'brought back newspapers, pamphlets and magazines - or knew or corresponded with people overseas' ${ }^{79}$ In the early 1980s Brouard and his partner at the time noticed that one of their friends, who had moved to the UK but who regularly visited South Africa, was getting increasingly ill. They speculated as to whether their friend had AIDS, but he never told them and they never asked. The friend subsequently died, ensuring that from early on in the epidemic, Brouard was acquainted with the reality of AIDS-related deaths.

Brouard saw that AIDS-related illness and death mobilised people both as individuals and as members of organisations: 'Those early responses were really located in the gay community. People ... mobilised around friends, tried to get support groups going ... tried to understand the treatment options available, and set up informal networks. ${ }^{80}$, Early individual activists included Gordon Isaacs and John Pegge. The latter was the

\footnotetext{
${ }^{78}$ Interview with Pierre Brouard, University of Pretoria, Gauteng, South Africa, 19 February 2008.

79 Ibid.

${ }^{80}$ Ibid.
} 
Director of GASA-6010, was HIV-positive and died of AIDS-related illnesses. ${ }^{81}$ Brouard commented on different political outlooks between organisations: 'GASA was ... the main . . organisation for more middle-class, mainstream, men and women and was apolitical' ${ }^{82}$ He recalls that gay organisations that were more 'left-orientated' appeared to be more active in Cape Town, than in Johannesburg.

Regardless of geographic location however, Brouard's retrospective sense of the situation was that 'middle of the road, white, gay men were really just trying to hold it all together in the absence of really much available [sic] ${ }^{83}$ Reflecting on the arrival of a serious new health concern Brouard suggested that aside from the emotional impact of the deaths of friends, family members, lovers and partners, the association of AIDS with homosexuality required people to address their sexuality without internalising AIDS as something that was inherently related to being gay. At the same time as challenging ideas that being gay was 'wrong, evil or sick', gay men were faced with a health crisis that was portrayed as being intrinsically linked to what was apparently 'gay sexuality'. Gay men thus had to address both internalised homophobia and societal perceptions of homosexuality being evil or sick, in the context of a new fatal disease that many medical professionals, politicians, media and religious groups directly linked to sexuality. ${ }^{84}$ The ramifications of AIDS affected both individual and community identity formation, as Brouard recalls:

... just to try and retain a sense of healthy sexuality and healthy identities when AIDS spoils your identity and spoils your sexuality ... that was a real challenge of those times. I remember having feelings like 'the community is self-destructing', there's just so much stuff going on, and people just aren't caring for themselves or each other.

It was an incredibly distressing and painful time to live through and people were just getting sick and ... AIDS ... struck the old and the young, and the beautiful and the ugly, the fat and the thin - it was a great equaliser .... My sense of the time, perhaps it was a psychological sense, was that some people who were the beautiful glittering stars of the gay firmament, were deeply shamed and humiliated and distressed about being HIV positive because it ... reduced them to their physicality and was ultimately a reminder that we are physical creatures and we get ill and we die and nobody is immune from that no matter how beautiful or glamorous you or your lifestyle are.

... it was really an incredibly fraught time to be gay and I don't know that, historically, if we look back, how that whole time affected the psyche of the gay community. To what extent it damaged it, or created a particular response or a feeling of what it means to be gay in the twentieth century. ${ }^{85}$

Research into how AIDS, the illegality of homosexuality, socially-sanctioned homophobia, apartheid ideologies and 'race' shaped gay male identity in South Africa historically is another area of research that requires further exploration. ${ }^{86}$ The hegemonic narratives around men and AIDS created by medico-scientific and political elites in South Africa and elsewhere in the early 1980s and not challenged significantly until

81 John Pegge was the Director of GASA-6010 and set up a branch of ACT-UP in Cape Town. See GALA GASA Collection particularly correspondence file and correspondence John Pegge to Jeff Neff (ACT-UP Los Angeles), 31 July 1991 (AM 2974). Gordon Isaacs is an academic and activist.

82 Interview with Brouard.

83 Ibid.

${ }^{84} \mathrm{Ibid}$. For an extensive discussion on how medical and political elites constructed and reinforced these links (or attempted to challenge them) see Tsampiras, op. cit. (note 7), chs 1-3. Discussions in this thesis reveal the problematic relationship between science and politics and the complexities of sexuality, sexual orientation, and constructions of 'race' and gender.

85 Interview with Brouard. 19 February 2008.

${ }^{86}$ For work on gay male identity and AIDS in the USA see S. Seidman, 'Transfiguring Sexual Identity: AIDS and the Contemporary Construction of Homosexuality', Social Text, 19/20 (1988), 187-205; and D. Altman, 'Transfiguring Sexual Identity: AIDS and the Contemporary Construction of Homosexuality: Comment', Social Text, 19/20 (1988), 207-9. 
the mid-1990s strongly suggested that it was not 'types' of sexual practices such as unprotected anal or oral sex, or higher-risk behaviours that needed to be examined, but rather something 'intrinsic to being gay' that was of concern. The focus in medical journals and parliamentary discussions, throughout the 1980s and mid-way into the 1990s, was thus not on sexual acts and practices that could be performed by sexually active people regardless of their sexual orientation, but rather on constructed AIDS avatars of 'deviant' gays, 'dirty' prostitutes, 'infected' foreigners, and 'sexually rapacious' 'black' people. This prevented serious attention from political and medico-scientific elites falling on male sexuality more broadly and assumed a normative, healthy, 'white' male sexuality. ${ }^{87}$ While these avatars were used to construct a hegemonic AIDS narrative, this does not mean that the narratives were not contested, challenged and reconfigured or rejected by some health care professionals such as Brouard.

Looking back Brouard recalls that the narratives of the time 'conflated identity with risk' and assumed that something about " "the gay condition" (or) "the gay being" presupposed vulnerability to AIDS to HIV'. ${ }^{88}$ This 'fitted in' with broader public health paradigms of the time that were modelled on popular understandings of sexuality, that did not sufficiently interrogate the relationships between sexual practice, sexual identity and basic biology. In this paradigm it was 'not the fluid that was the problem, it was who you were that posed the risk'. 89

This understanding of sexuality and confusion over sexual practice and sexual identity resulted in 'a lot of mythologizing even in the medical sphere' ${ }^{90}$ Brouard recalled counselling a heterosexual couple in the Esselen Street Clinic where the man was concerned about their risk of HIV infection because they practised anal sex. Further questioning revealed that they were both HIV-negative and in a committed monogamous relationship. Brouard explained that, in light of this, they were not likely to be at risk of HIV as it was not the practice of anal sex per se, that was the primary risk, but rather bodily fluids containing the HI virus. These and other experiences left Brouard with a sense that, for many people, understandings of AIDS and HIV transmission, and sexuality more broadly, 'were very mystifying and mystified'. ${ }^{91}$

Brouard started counselling people in the early to mid-1980s through his involvement with GAB (Gay Advice Bureau) a counselling service providing support for gay people or people exploring their sexuality. At that time GAB was not dealing with many HIV-positive people but one of Brouard's colleagues was diagnosed with AIDS so GAB established an informal support system for him and his partner. After his death, GAB launched an unsuccessful support group for people living with HIV.

While completing his master's degree Brouard volunteered at the AIDS Centre at the SAIMR, which opened to the public in January $1988 .{ }^{92}$ It offered an evening counselling

\footnotetext{
87 Tsampiras, op. cit. (note 7). Extensive examples of the evolution of these narratives and how they changed over time are discussed in detail in this thesis - see specifically chs 1-2. The specific relationship between constructions of 'race', 'black sexuality' and racism in science in relation to AIDS narratives is the subject of an article forthcoming in 2014.

${ }^{88}$ Interview with Brouard. 19 February 2008.

89 Ibid.

90 Ibid.

91 Ibid.

92 GALA - GASA Collection (AM 2974), Correspondence from Susan Hyde, AIDS Centre, SAIMR, to Diana, GASA, 1 June 1989.
} 
and testing clinic where Brouard did pre- and post-test counselling with the predominantly 'white', gay clients. He and a friend also established an HIV support group attended by a small number of gay men, which allowed Brouard and his friend 'to explore what it means to be positive, and what support one needed, and what was out there'. ${ }^{93}$

During his internship year as a master's student in 1989, Brouard volunteered at the HIV Clinic at Joburg Gen doing informal counselling and support work, and acting as a 'resource person'. He recalls that 'people like Ruben Sher, Dennis Sifris and Steve Miller ran the clinic ... and it was a fascinating period because it was very "other". ${ }^{94}$ While the hospital was still racially segregated and primarily served the needs of 'white' patients, these doctors and patients were 'other' because of their sexual orientation or because of the demands that they made on the hospital on behalf of gay people:

... suddenly this group of gay men who were feeling more entitled in some ways, or more informed, or more empowered, were coming in and it created some envy and resentment among the medical fraternity because why was there a need for a special clinic? AIDS was still very much a disease of gay men, it was still stigmatised, and Dennis, Ruben and Steve had to really fight to get staff, to get funds. They had constant battles with hospital management. ${ }^{95}$

In the context of apartheid ideology that sought to categorise people in unambiguous ways and thereby create specific, often binary, identities, 'white' gay men were 'problems' as they not only transgressed accepted heteronormative identities, but were also criminalised. They were men and so were expected to occupy a particular place in patriarchal structures, and they were 'white' and thereby afforded the privileges of their 'race'. They were, however, gay men and therefore their privileged status in terms of masculinities could be called into question. ${ }^{96}$ Instead of being shamed into silence by their sexual orientation, these men took advantage of the social capital they had as 'white' elite medical professionals, and challenged hospital authorities. Unsurprisingly they antagonised others in positions of privilege both within, and beyond, the health sector.

Brouard recalled how the accessibility of ARVs at Joburg Gen highlighted the class dynamics inherent in a health care system divided into public and private sectors. He felt ineffectual at the Clinic 'because it seemed to be an overwhelming problem and you just saw so much death and dying, and just sadness and grief'. Sifris and Miller saw patients who could afford ARVs at their private practices, but there was no hope of this at the Joburg Gen. By the early 1990s both Sifris and Miller had left the Clinic and worked predominantly in their private practices. Brouard in the meantime, continued to volunteer at Joburg Gen and got a job in Hillbrow at the Esselen Street Clinic with Mary Crewe and Clive Evian, who were starting up the Johannesburg City Council AIDS programme.

Despite being state-funded, and having to negotiate the complexities of national and local budgetary funding processes, Brouard maintains that he, Evian, Crewe and others

93 Interview with Brouard. 19 February 2008.

94 Ibid.

95 Ibid.

96 Definitions of 'masculinities' are drawn from work by Robert Morrell who notes that 'Masculinity is a collective gender identity and not a natural attribute. It is socially constructed and fluid. There is not one universal masculinity, but many masculinities.' which are 'not fixed character types but configurations of practice generated in particular situations in a changing structure of relationships': R. Morrell, 'Of Boys and Men: Masculinity and Gender in Southern African Studies', Journal of Southern African Studies, 24, 4 (December 1998), 605. In this article the phrase is used to denote an idea of 'white' masculinity' presented as the norm against which ruling white elites judged other masculinities. 
pioneered several innovative programmes relating to sexual health and STIs at the Esselen Street Clinic. Brouard, for instance, started a closed support group along strict psychotherapeutic lines for HIV-positive gay men which ran for three years. ${ }^{97}$ With so little access to AZT the primary focus of the group was on how to adapt to living with HIV and preparing to die of AIDS. Several of the group members did die - Brouard remembers those years as his 'most significant immersion into counselling people who were dying or confronting mortality'. ${ }^{98}$

Brouard recounts that the Clinic was not a specific AIDS or HIV clinic but rather provided comprehensive sexual health services with an AIDS training and support component. It had family planning services, a TB clinic, an STI clinic that incorporated HIV antibody testing, and an outreach programme focused on sex workers and gay men. Brouard remembers the Clinic being used by all sectors of the Hillbrow community and being told by clients that it developed a reputation for meeting the needs of all people in the community and for being 'gay friendly'. ${ }^{99}$

Brouard knew many of the people who came to the clinic for help, and, despite minimal resources, recalls that they never turned people away. The clinic became a space where community members or groups could collaborate and develop new AIDS intervention strategies such as drama productions, comic strips and other innovative education materials. The clinic ran a support group for 'black' womyn, helped run 'AIDS weeks', and in 1991 piloted AIDS education adverts on public buses. ${ }^{100}$ Brouard maintains that they also developed interesting training models and counselling courses hailed as innovative by other health care centres, and provided 'non-judgemental' testing services and STI treatments.

In addition, Brouard suggested the background and politics of the staff and a guiding assumption that responses to STIs required a multi-disciplinary rather than a solely medico-scientific approach influenced the integrative outlook of the Clinic. Brouard referred to the 'interesting mix of people' and the variety of skills that coalesced at the clinic, with Clive Evian bringing a community medicine perspective while Mary Crewe applied her academic knowledge to understanding the sociological roots of AIDS to provide a foundation for implementing programmes at the clinic.

\section{Changes and Transitions}

While sexuality organisations or gay professionals could exert pressure on policy makers in the UK and USA, or influence the AIDS policy-making process itself, there was less opportunity for this in South Africa. ${ }^{101}$ In the 1980s the criminalisation of homosexuality and the government's homophobic stance made engagements between sexuality activists and government officials complicated. The political transition in the early 1990s created

\footnotetext{
${ }^{97}$ Interview with Brouard. 19 February 2008.

98 Ibid.

${ }^{99}$ Ibid.

100 See C. R. Evian et al., 'Evaluation of an AIDS Awareness Campaign using City Buses in Johannesburg', South African Medical Journal, 80, 7 (5 October 1991), 343-6.

101 See V. Berridge, AIDS in the UK: The Making of Policy, 1981-1994 (New York: Oxford University Press, 1996); and V. Berridge, 'The early years of AIDS in the United Kingdom 1981-6: Historical perspectives' in T. Ranger and P. Slack (eds), Epidemics and Ideas: Essays on the Historical Perception of Pestilence (Cambridge: Cambridge University Press, 1992).
} 
more opportunities for sexuality activists to engage with decision-makers but the focus for sexuality activists was no longer only on fighting legislation, or even raising awareness about AIDS, but rather on securing citizenship rights and equality for people of all sexual orientations. $^{102}$

In the late 1980s and early 1990s the Clinic built more alliances, both nationally and locally with progressive organisations in the gay communities like the Gay and Lesbian Organisation of the Witwatersrand (GLOW) and the TAP. Alliances were also built between progressive organisations involved in AIDS work; and between gay organisations, activists, and the Clinic. ${ }^{103}$ Simon Nkoli was involved in GLOW and TAP, and with Brouard ran HIV prevention workshops in Hillbrow for 'black', gay men based on sex-positive, risk reduction approaches. ${ }^{104}$ In addition to providing information and distributing condoms, they used the workshops to explore relationships, sexuality and identities. Brouard and Nkoli criticised the 'Abstain, Be Faithful, use Condoms' ('ABC') programmes and messages that were most prominent at the time, concluding that gay communities would not be receptive to the moralistic, conservative messages. Nkoli had an office in Esselen Street and started an organisation for HIV-positive 'black', gay men. Brouard recalls how 'you would walk into his office and there were all these explicit posters of naked black men - so he was fantastically subversive'. ${ }^{105}$

Nkoli, Brouard and Sifris, as well as organisations like the Gay Peoples' Health Forum, and GASA-6010/ASET, were responsible for subverting the conservative, homophobic, moralistic narratives about sex and sexuality by virtue not only of their sexual orientation and politics, but also because of the safer sex material that they distributed or produced. In stark contrast to the government's 'ABC' messages, the AIDS education material developed by gay organisations or AIDS support groups in the mid-1980s, was radically different in both messaging and in assumptions about the intended audience. As the examples pictured below reveal, images and messages from gay organisations treated the audience as sexually active and did not assume that abstinence was realistic. Instead, the images and words encouraged safer sex practices as a normalised part of enjoyable, erotic, healthy, sexual activity, and depicted sex across 'colour lines'.

Brouard was on an editorial board that produced a comic pamphlet called 'Keep It Hot, Safe and Gay' which featured two characters, Hot Shot and Safe Sex - a lycra-clad super hero and a condom - who delivered unabashed information about anal sex, oral sex, thighsex and mutual masturbation (figure 1). Information about HIV infection and transmission was underscored by a central message that 'Playing safe with the one you love puts the fun back in and takes the danger out'. ${ }^{106}$ The comic provided contact information for the Esselen Street Clinic and gay organisations.

\footnotetext{
102 Hoad et al. (eds), op. cit. (note 11), Part 2: The Constitution.

103 The AIDS Consortium was 'a loosely structured affiliation of about 50 organisations active in the AIDS/HIV field' and provided a platform for organisations to work together, especially prior to the National AIDS Convention of South Africa (NACOSA) which was held in 1992 to discuss how to address AIDS and brought together representatives from government, the progressive health movement, community organisations, other civil society organisations, and liberation organisations. See GALA - Triangle Project Papers AM2974, AIDS Consortium Minutes B9.1.

104 The histories of early responses to AIDS by 'black' sexuality activists living in South Africa remain largely unwritten and require further research.

105 Interview with Brouard. 19 February 2008.

106 Pierre Brouard - Private Collection, 'Keep It Hot, Safe and Gay’ pamphlet, $c$. late 1980s, early 1990s
} 
(a)

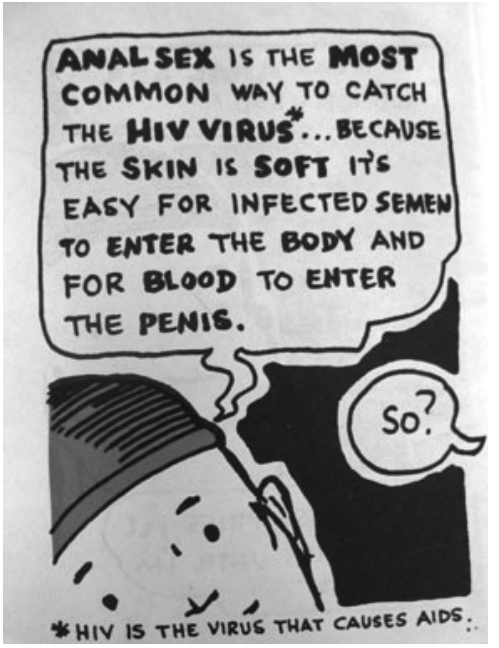

(b)

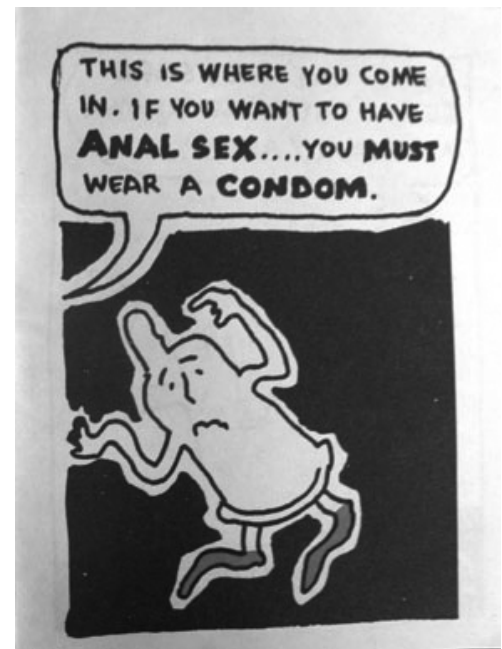

(c)

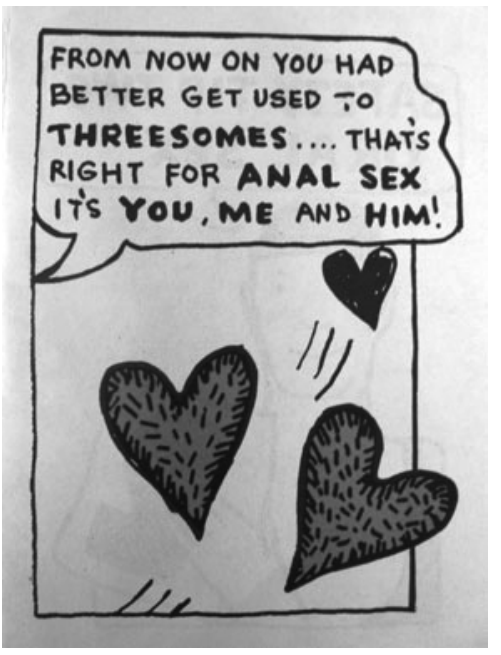

Figure 1: Panels from 'Keep It Hot Safe and Gay'. ${ }^{107}$

Safer sex cards from the Johannesburg-based Gay Peoples' Health Forum (GPHF) were designed as actual postcards with writing space, and included the organisation's contact information. Some of the cards showed a "white' man and a "black" man in intimate poses and reminded recipients to protect their partners and declared that healthy sex was not boring (figure 2).

The significance of these media needs to be considered in light of homosexuality being illegal, and 'interracial' hetero(sex) only having been decriminalised in 1985. Producing 
(a)

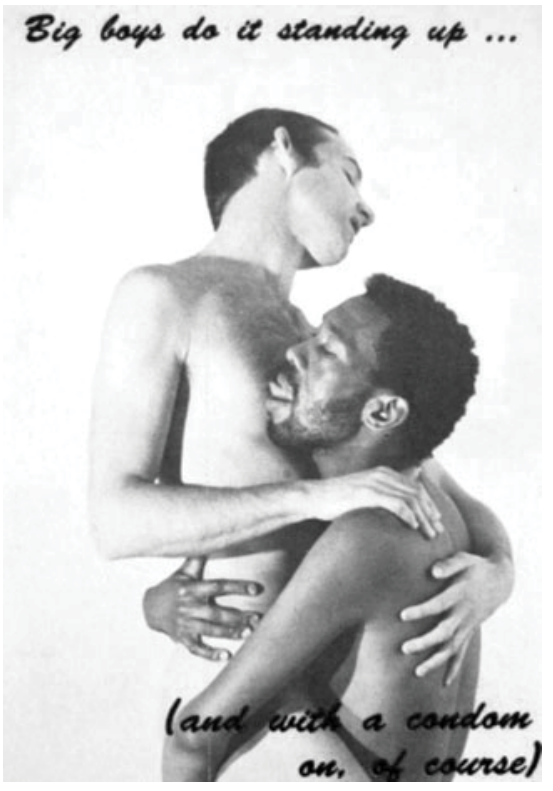

(b)

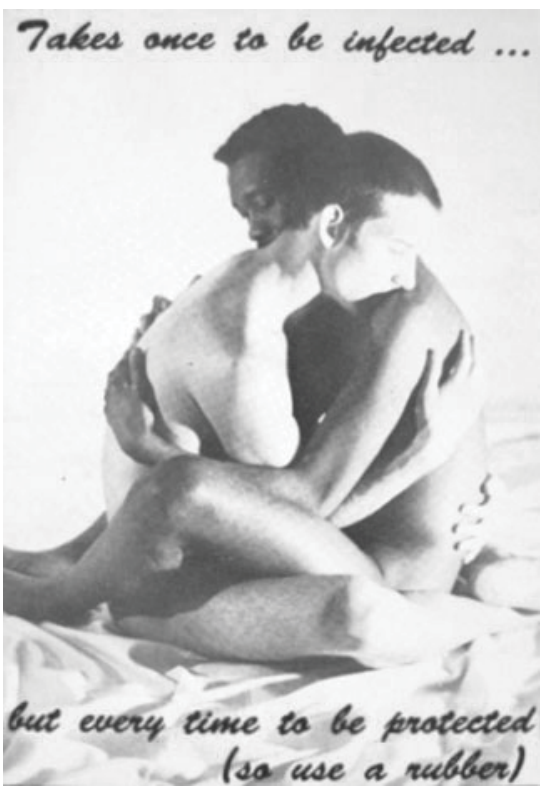

Figure 2: The Gay Peoples' Health Forum's safer sex postcards. ${ }^{108}$

and distributing these education materials was socially (and legally) subversive and the content of their sexual health messages was radical by the standards of the day.

Much like the 'Keep It Hot' pamphlet and the GPHF postcards, safer sex cards distributed by ASET in Cape Town combined basic facts about HIV transmission with contact information for the organisation. The cards also used frank language and (for the time) explicit images, such as a 'black' and 'white' men kissing, to convey their message. The photographic credits indicate that some images were reproduced from the Terence Higgins Trust in London, while others were created for the organisation. ${ }^{109}$ In 1991 John Pegge, the director of the organisation, confirmed the importance of information exchanges between international organisations:

We run a large Safer Sex campaign amongst the Gay [sic] minority and for this purpose we use Safer Sex posters donated to us by Gay AIDS service organisations in other countries. We have a wide selection from Australia, New Zealand, the United Kingdom, the Netherlands, Canada and the United States of America. ${ }^{110}$

These images depicting a sexuality that was still criminalised flew in the face of South Africa's conservative pornography laws which organisations managed to circumvent. The state of transition in the country was such that ASET was able to receive such material, despite it 'running foul' of pornography legislation, because authorities no longer appeared certain of quite which legislation was applicable. When apartheid laws were being more rigorously implemented, 'pornography' received by mail did not result in criminal prosecution if the recipient could prove that they had not solicited the material.

108 GALA - ASET Collection (AM 2974).

109 GALA - ASET Collection (AM 2974).

110 GALA - GASA Collection (AM 2974), Correspondence, John Pegge, GASA 6010, to Benjamin Hal, B M Switchboard, 16 October 1991. 
Nonetheless, Pegge urged caution: 'I would suggest that you send any materials that might be deemed pornographic in a separate envelope without a covering letter'. ${ }^{111}$ Despite the caution urged by Pegge, the socio-political milieu of the country seemed to be changing.

In the early to mid-1990s, Brouard witnessed a change in Clinic clients. Rather than the initial client base of predominantly 'white' gay males, there were now more heterosexual people and 'black' South Africans returnees who had either lived in exile communities or travelled to other countries. One womyn that he counselled frequently had been involved with a senior operative of the armed wing of the ANC Umkhonto weSizwe (MK). The MK soldier attended counselling only once and later died of AIDS.

Yet, this time also saw a renewed sense of hope derived both from the country's political transition to a Constitutional democracy and from developments in ARV treatments. At the same time, progressive health organisations became increasingly involved in AIDS work and approached the Clinic to obtain training materials and discuss mobilising health workers. Brouard recalls:

[while] the epidemic was still 'othered' in South Africa . . . it was the build up to ' $94 \ldots$ and the whole NACOSA (National AIDS Convention of South Africa) process had generated an incredible amount of coming together and talking and debating a first national (AIDS) plan. People were pulling together more ... it was ... a fascinating time to be living through. ${ }^{112}$

The space for gay health care professionals to influence national AIDS programmes and policy throughout the 1980 s and into the early 1990s was, Brouard suggests, hampered by the level of homophobia in public health structures. While gay men, like Brouard himself, were involved in the government-funded AIDS Training and Information Centres (ATICS), they worked within 'a conventional public health paradigm ... (doing) ...testing, counselling training, community prevention, (and) fairly dull ... AIDS in the workplace stuff'. Within this conventional paradigm, it was difficult for gay activists to bring about radical changes in AIDS education messaging or campaigns, so their influence would have been primarily at the individual level, with people they counselled, or, possibly, within the ATIC structures.

Brouard maintains that even people such as Ruben Sher, as an AGA member, would have had limited opportunities to make substantive changes to national AIDS policies or programmes. With AIDS ring-fenced as something 'other' and outside the public health care system, it was seen as a challenge to existing health care systems and structures. Brouard recalls that even at the Clinic, which championed an integrated approach to sexual health, nursing and other staff who were less involved in AIDS work saw 'the AIDS people as different'. ${ }^{113}$ Brouard noted that the perception of AIDS as 'other' is still prevalent in contemporary public health debates.

When interviewed for this project, Brouard remarked that he was struck by the irony that state resources for AIDS programmes amongst LGBTI communities were not available either during or after apartheid. Brouard had met Rina Venter (the last NP National Minister of Health) in the early 1990s and he recalled that she had made it clear that

111 GALA - GASA Collection (AM 2974), Correspondence, John Pegge, GASA 6010, to Bob Webster, Hamilton AIDS Network for Dialogue and Support, 15 May 1991. Before distributing the cards in 1993 Pegge sent a set to Edwin Cameron who wrote a legal opinion for ASET concluding that, given changing censorship provisions, the cards would not be found 'undesirable' see GALA - Cameron Collection (AM 2629), HIV/AIDS Material, Correspondence, John Pegge, ASET, to Edwin Cameron, Centre for Applied Legal Studies, 29 October 1992; and Edwin Cameron, Legal Opinion on Imported AIDS Educational Material for Gay Clients for ASET, 6 March 1993.

112 Interview with Brouard. 19 February 2008.

113 Ibid. 
because AIDS was a 'minority issue' the gay community 'needed to look after itself'. This attitude, combined with the criminalisation of homosexuality, meant that state resources were not made available to gay people. Similarly, in the post-1994 period, when the focus of government interventions shifted to heterosexual people and pregnant womyn and people started claiming their Constitutionally-guaranteed rights to health care and treatment (in this instance ARV therapy) and demanding responses from the ANC-led government, gay communities were again sidelined as minority groups. This continued marginalisation has resulted in a lack of basic information about HIV transmission and infection rates amongst gay communities in post-apartheid South Africa. ${ }^{114}$

Of the early years of the epidemic Brouard primarily recollects death: 'there was a lot of death - that's what I remember of those years ... The number of funerals one went to, the number of people who disappeared, it was just horrible'. ${ }^{115}$ While in 2013 the funerals continue, the option for a longer life is now available to people if regular and sustained access to ARVs can be maintained by the state, and in 2013 South Africa has what is possibly one of the largest ARV rollout programmes in the world. Brouard continued working at the Clinic until 1997 and then joined the Centre for the Study of AIDS (CSA) in 1999. As the Deputy Director of the CSA, Brouard continues to conceptualise and develop training methods and materials, and contributes to academic publications and other fora on topics such as psychosocial issues, gender, sexuality, human rights, testing and tertiary responses to HIV and AIDS. ${ }^{116}$ Brouard's work still involves the realities of AIDS-related deaths, but now also includes components that address prolonging and living life fully, regardless of HIV status.

\section{Conclusion}

Personal and professional relationships and networks organised around sexual identity were important to the first responses to AIDS in South Africa in both medical and social spheres. Sexuality organisations had to take responsibility for addressing the AIDS epidemic in the face of government inaction, but much of this response was limited to specific sections of the gay community, individuals, and to specific geographic areas.

While AIDS provided a point of mobilisation and support in South Africa, 'race', class, gender and sexuality divided gay communities' responses to AIDS. As this article has explored, Sifris and Brouard were active in both sexuality organisations and in two key public health sites involved in addressing AIDS. Their accounts of the time provide insights into the experiences of two gay men at the start of an epidemic 'written on' and around gay men's bodies. Their stories, as reflected here show how even within hostile government-aligned health care spaces, they were able to provide support and treatment to some people, and to engage in, what were for the time, socially subversive activities. The different contexts and professional fields in which they found themselves mediated

\footnotetext{
114 Ideally transmission and infection rates for people would be available based on a variety of factors including economic security, geographic location, age, sexual practices and abilities. There is a difference between constructing an epidemic such that it focuses inappropriately on people defined as belonging to a particular group, rather than sensitively ensuring there is sufficient information and support for communities of people whose sexual health needs may be context-specific.

115 Interview with Brouard. 19 February 2008.

116 See the Centre for the Study of AIDS website at www.csa.za.org/contact/67-management/2-pierre-brouard (accessed 11 February 2014). See also P. Brouard, 'Gender, same-sex sexuality and HIV/AIDS in South Africa: Practical research challenges and solutions', in Reddy et al., op. cit. (note 2).
} 
their individual experiences, but in both men's case, the hegemonic AIDS narratives about homosexuality influenced and shaped their responses even as they challenged them.

Homophobic beliefs, conservatism, or any other invisible or unquestioned ideologies that influence understandings of epidemics and practical responses to them, have tangible repercussions. These repercussions may be evident in the lack of legal protection or in the emotional costs of prejudice and intolerance. Brouard, like Miller and Sifris, challenged hospitals to provide care for people with AIDS. Joburg Gen was often reluctant to admit people with AIDS, as providing palliative care was seen as a 'waste of resources' and of 'limited value' for instructional purposes. ${ }^{117}$ Nursing and other staff were often unwilling even to touch AIDS patients. ${ }^{118}$ Even when places could be found for people it was difficult to get staff members to treat them with dignity; and many staff members did not 'deal well with gay men, young men, coming in infected and dying of this strange disease (where) dementia complicated the death process further'. ${ }^{119}$

For the partners of the men who died the trauma of loss was aggravated by their lack of legal status or recognition as partners of the deceased. Brouard, for instance, recalls counselling loving partners who were not able to claim the bodies of the deceased men. He witnessed both the deaths and the grief of survivors during this time.

In the early phases of the epidemic Sifris challenged homophobic responses to gay men with AIDS, but did not necessarily challenge the then dominant narrative that initially linked AIDS to being gay. Given that the professional and personal spaces he occupied bore out the narrative that gay men were the ones dying of AIDS, this is perhaps not surprising. Brouard worked within gay communities he most identified with, but his professional and personal spaces seemed to have presented a more complex narrative about AIDS and its association with sexual identity and broader identity politics.

The socio-political evocation of stereotypes, or constructions of gender, 'race', and sexual orientation - have long shaped experiences of (ill)health and epidemics. This article has focused on the micro-narratives of individuals and their responses to the epidemic as individuals and as part of communities. It serves as a reminder of the intricate and intimate relationships between ideologies, illness and identities, but also that behind each AIDS avatar evoked in hegemonic narratives are complex, embodied people.

\footnotetext{
117 Oppenheimer and Bayer, op. cit. (note 19), 31.

118 Ibid., 32-6.

${ }^{119}$ Interview with Brouard. 19 February 2008.
} 